\title{
Batik Sebagai Media Dakwah pada Asosiasi Aksi Muda Bina Griya Kota Pekalongan
}

\author{
Saebani $^{1}$, Teguh Purwanto ${ }^{2}$, Bayu Wirawan Dwijo Saputro ${ }^{3}$ \\ Universitas Muhammadiyah Pekajangan Pekalongan, \\ Jl. KHM Mansyur No. 2 Bendan Kota Pekalongan. (0285) 434444 \\ ${ }^{1}$ Program Studi Ekonomi Syariah Universitas Muhammadiyah Pekajangan Pekalongan \\ ${ }^{2}$ Program Studi Manajemen Universitas Muhammadiyah Pekajangan Pekalongan \\ ${ }^{3}$ Program Studi Diploma III Teknik Batik, Politeknik Pusmanu Pekalongan \\ ${ }^{1}$ saebani123@gmail.com, ${ }^{2}$ iuanmambo@yahoo.coid, ${ }^{3}$ bayuwirawands@gmail.com
}

\begin{abstract}
Abstrak
Kota Pekalongan terkenal dengan julukan kota batik dan juga terkenal dengan nuansa religiusnya karena mayoritas penduduknya memeluk agama Islam. Dengan batik dan religiusitas di kota Pekalongan menggerakkan Asosiasi Aksi Muda dalam pemberdayakan umat melalui kegiatan kewirausahaan, salah satu bentuk wirausahanya adalah membuat kaligrafi. Akan tetapi perkembangan kaligrafi ini mengalami beberapa kendala diantaranya 1) Belum diterapkannya praktik bisnis Islam, 2) Belum adanya produk ciri khas kaligrafi, 3) Rendahnya produktifitas produksi dan 4) Perlunya manajemen pemasaran. Solusi yang ditawarkan adalah Batik dakwah project, yang diharapkan dapat membantu menyelesaikan permasalahan mitra tersebut. Metode pendekatan yang digunakan untuk pelaksanaan kegiatan pengabdian kepada masyarakat adalah metode pemberdayaan masyarakat partisipatif atau Participatory Rural Apraissal (PRA). Dengan kondisi seperti tersebut diatas, maka program yang kami usulkan adalah, Program kreatifitas batik, dengan judul tema PKM Batik Dakwah berupa: Kelas project 1 yang menanamkan keilmuwan dan praktek etika bisnis Islam. Kelas project 2 menumbuhkan kecintaan kepada motif batik pekalongan Kelas project 3 menciptakan inovasi produk yang belum pernah ada dengan mengedepankan keberkahan produk Kelas project 4 pemahaman tentang persaingan usaha dan pembuatan digital marketing berupa instagram. Produk yang dihasilkan berupa Kaligrafi yang dipadukan dengan ukiran batik khas pekalongan, dan terdapat peningkatan omset bagi mitra binaan.
\end{abstract}

Kata kunci : Kaligrafi, Batik dakwah, Pemasaran dan Produksi.

\section{PENDAHULUAN}

a. Latar belakang

Kota Pekalongan adalah salah satu kota di pesisir pantai utara Provinsi Jawa Tengah. Kota ini berbatasan dengan Laut Jawa di utara, Kabupaten Pekalongan di sebelah selatan dan barat dan Kabupaten Batang di timur. Kota Pekalongan terdiri atas 4 kecamatan, yakni Pekalongan Utara, Pekalongan Barat, Pekalongan Selatan dan Pekalongan Timur. Kota Pekalongan terletak di jalur pantai utara Jawa yang menghubungkan Jakarta-SemarangSurabaya. Kota Pekalongan berjarak $384 \mathrm{~km}$ di timur Jakarta dan $101 \mathrm{~km}$ sebelah barat Semarang. 
Kota Pekalongan mendapat julukan kota batik. Hal ini tidak terlepas dari sejarah bahwa sejak puluhan dan ratusan tahun lampau hingga sekarang, sebagian besar proses produksi batik Pekalongan dikerjakan di rumah-rumah. Akibatnya batik Pekalongan menyatu erat dengan kehidupan masyarakat Pekalongan. Batik telah menjadi nafas penghidupan masyarakat Pekalongan dan terbukti tetap dapat eksis dan tidak menyerah pada perkembangan jaman, sekaligus menunjukkan keuletan dan keluwesan masyarakatnya untuk mengadopsi pemikiran-pemikiran baru.

Kota Pekalongan juga terkenal dengan nuansa religiusnya karena mayoritas penduduknya memeluk agama Islam. Ada beberapa adat tradisi di Pekalongan yang tidak dijumpai di daerah lain misalnya: syawalan, sedekah bumi, dan sebagainya. Syawalan adalah perayaan tujuh hari setelah lebaran dan sekarang ini disemarakkan dengan pemotongan lopis raksasa yang memecahkan rekor MURI oleh walikota untuk kemudian dibagi-bagikan kepada pengunjung.

Di Pringrejo terdapat perumahan Bina Griya, disanalah terdapat perkumpulan pemuda yang memiliki semangat pemberdayaan umat. Perkumpulan pemuda tersebut bernama Asosiasi Aksi Muda. Asosiasi Aksi Muda ini merupakan wujud dari kepedulian pemuda terhadap pemberdayaan masyarakat dengan tetap berpegang teguh pada tradisi budaya Indonesia, khususnya dalam pelestarian batik di kota Pekalongan. Semangat dan kreatifitas pemuda sangatlah dinantikan oleh masyarakat, hal ini dikarenakan pemuda akan menjadi penerus peradaban, budaya dan cita-cita perjuangan. Masa depan bangsa sangatlah ditentukan oleh para generasi muda.

Dalam upaya mewujudkan cita-cita tersebut, Asosiasi Aksi Muda Bina Griya sadar akan pentingnya pelestarian batik, karena sudah menjadi kultur dari peradaban di Pekalongan. Inisiatif pelestarian batik ini dikolaborasikan dengan sifat kereligiusan masyarakat Pekalongan. Penggabungan batik dan kereligiusan ini membuat Asosiasi Aksi Muda berinisiasi membuat sebuah konsep batik sebagai media/sarana dakwah. Program Asosiasi Aksi Muda Bina Griya Pringrejo memiliki program wirausaha. Program ini adalah usaha menyatukan batik dengan kaligrafi. Demi memadukan batik dan religiusitas. Kaligrafi ini kedepannya akan diberi sentuhan batik. Lokasi produksi sampai saat ini bersifat sewa rumah, berada di Perumahan Bina Griya Barat, Jln. Elok No. 29. Kelurahan Pringrejo, Kecamatan Pekalongan Barat - Kota Pekalongan. Dengan luas total area bangunan dan halaman sekitar $600 \mathrm{~m}^{2}$. Bangunan inilah yang menjadi aktivitas program sosial preneur Asosiasi Aksi Muda Bina Griya. 
b. Perumusan Masalah

Permasalahan yang dihadapi mitra cukup kompleks dimulai dari Inovasi Produk, Produksi, Pemasaran, komunikasi penjualan, adminiastrasi bisnis, tata kelola keuangan dan lain-lain. Akan tetapi mengingat keterbatasan waktu, tenaga, dan biaya maka dilakukan diskusi dengan mitra untuk menentukan permasalahan yang diprioritaskan untuk segera diselesaikan.

Berdasarkan hasil diskusi dan kesepakatan dengan perwakilan Asosiasi Aksi Muda melalui Forum Discussion Group (FGD), maka dalam kegiatan pengabdian kepada masyarakat ini ada empat (4) permasalahan yang disepakati untuk diselesaikan yaitu:
a. Perlunya pengetahuan bisnis yang sesuai syariat Islam
b. Perlunya Inovasi produk
c. Perlunya peningkatan produksi
d. Perlunya manajemen pemasaran yang baik

\section{METODE}

Metode pendekatan yang digunakan untuk pelaksanaan kegiatan pengabdian kepada masyarakat adalah metode pemberdayaan masyarakat partisipatif atau Participatory Rural Apraissal (PRA). PRA adalah suatu metode pendekatan dalam proses pemberdayaan dan peningkatan partisipasi masyarakat, yang tekanannya pada keterlibatan masyarakat dalam keseluruhan kegiatan yang dilaksanakan. Seluruh rangkaian kegiatan akan dilaksanakan kurang lebih selama 8 bulan. Tahap-tahap dari model PRA adalah sebagai berikut:

a. Pengenalan masalah/kebutuhan dan potensi serta penyadaran

Pada tahap ini dilakukan identifikasi terhadap berbagai permasalahan yang dihadapi oleh mitra. Melalui mekanisme Forum Discussion Group (FGD), permasalahan yang dihadapi oleh mitra terangkum dalam empat aspek, yaitu aspek Bisnis Islam, Inovasi Produk, Produksi Islam, dan Manajemen Pemasaran.

b. Penetapan prioritas

Masalah-masalah yang sudah teridentifikasi selanjutnya dirangking urut dari masalah yang paling berat hingga ke masalah yang ringan. Permasalahan utama yang dihadapi mitra adalah belum diterapkannya praktek bisnis yang sesuai syariat Islam. Permasalahan kedua belum adanya inovasi produk yang menjadi ciri khas mitra dan inovasi dapat menjadikan batik sebagai media dakwah. Kemudian permasalahan berikutnya adalah produktifitas produksi yang kurang sehingga jauh dari target produksi yang diharapkan. 
Dan yang terakhir adalah kemampuan manajemen pemasaran usaha yang tidak memadai sehingga hanya memasarkan produk ala kadarnya.

c. Penentuan solusi pemecahan masalah

Tim pengusul melaksanakan Forum Discussion Group (FGD) tahap II dengan mitra untuk menentukan alternatif pemecahan masalah yang sudah diprioritaskan, termasuk penentuan jadwal kegiatan, tempat pelaksanaan, dan peserta yang mengikuti kegiatan pengabdian kepada masyarakat. solusi pemecahan masalah yang disepakati adalah Batik Dakwah Project.

d. Perencanaan penerapan gagasan dan penyajian rencana kegiatan

Tahap ini disusun oleh tim pengusul dengan tetap melibatkan mitra, sehingga pelaksanaannya tertib dan lancar serta dapat optimal hasilnya. Tim pengusul akan menyusun kurikulum, rencana pembelajaran, dan modul batik dakwah project.

e. Pelaksanaan pengorganisasian

Pada tahap ini, tim pengusul akan melakukan pembagian tugas sesuai dengan kepakaran yang dimiliki dan berkoordinasi dengan mitra pendukung untuk mensukseskan kegiatan yang akan dilakukan

f. Sosialisasi kegiatan

Tim pengusul mensosialisasikan kegiatan "batik dakwah project" yang akan dilaksanakan kepada dinas terkait dan kedua mitra. Pada tahap ini, mitra akan diberi informasi tentang segala hal yang berkaitan dengan "batik dakwah project" dan dimotivasi agar tergerak untuk mengikuti program ini.

g. Pelaksanaan kelas batik dakwah project

Batik dakwah project berbentuk pertemuan rutin yang bersifat klasikal dan diskusi. Project ini dilakukan selama 12 - 15 pertemuan. Materi yang akan disampaikan berbentuk materi umum dan materi khusus. Materi umum yang akan dipaparkan adalah sebagai berikut.

1) Materi bisnis yang sesuai dengan syariat Islam

2) Materi inovasi berupa filosofi motif batik khas Pekalongan

3) Materi produksi terkait dengan produksi dalam bisnis Islam

4) Materi manajemen pemasaran terkait dengan perencanaan pemasaran, analisa persaingan, kemitraan dagang, digital marketing dan lain sebagainya.

Sedangkan materi khusus adalah materi yang disesuaikan dengan kondisi pada mitra yang didasarkan pada assessment dan hasil diskusi dalam kelas batik dakwah project. Seluruh materi yang disampaikan merupakan kombinasi dari teori dan praktik / aplikasi. 


\section{HASIL DAN PEMBAHASAN}

a. Pemahaman Etika Bisnis Islam

Etika Islam adalah norma-norma dalam pengelolaan harta dalam agama Islam, menjalankan suatu usaha menurut agama Islam adalah pengelolaan harta yang tidak hanya mencari keuntungan material tetapi juga keuntungan immaterial dengan mengedepankan aturan-aturan dalam agama Islam

Bisnis sesuai syariat Islam adalah kewajiban bagi setiap muslim. Karena dalam hukum Islam telah terdapat aturan-aturan pada praktik jual-beli. Dalam pelaksanaan bisnis Islam ada tahapan-tahapan yang harus dilakukan oleh setiap muslim (Kelas Project Etika Bisnis Islam Pertemuan 1-7, 2019), diantaranya adalah

1) Niat

Segala sesuatu harus ada niatnya, karena hasil usaha tergantung pada niatnya, Praktik pengucapan niat, bacaan awal usaha dan bacaan akhir usaha

2) Tujuan Usaha

Mendapatkan keberkahan, mendapatkan Falah (sukses). Dalam Islam untuk mendapatkan berkah dan fallah adalah ikhlas dan mengikuti jejak Nabi Muhammad SAW.

3) Halal dan Tayib

Islam mengajarkan dalam mencari rezeki (berusaha) harus halal dan tayib (baik) sehingga Islam adalah agama yang menjaga dirinya dari hal-hal yang tidak baik dan haram, karena pengaruh halal dan baik itu akan menjadikan keberkahan dan kesuksesan.

b. Inovasi Produk dan Filosofi Batik Pekalongan

Kelas Project Inovasi Produk dan Filosofi Batik berupa pelatihan pemahaman motif batik pekalongan. Motif batik pekalongan ini nantinya akan dipadukan dengan kaligrafi.

Inovasi produk kaligrafi diperlukan karena produk kaligrafi yang ada saat ini belum memiliki ciri khas dan jati diri. Padahal produk yang baik adalah produk yang memiliki nilai keunikan yang tidak akan ditemukan pada produk-produk lainnya termasuk produk kaligrafi. 
Adapun hasil dari pelatihan dan produk kaligrafi batik adalah seperti berikut ini:

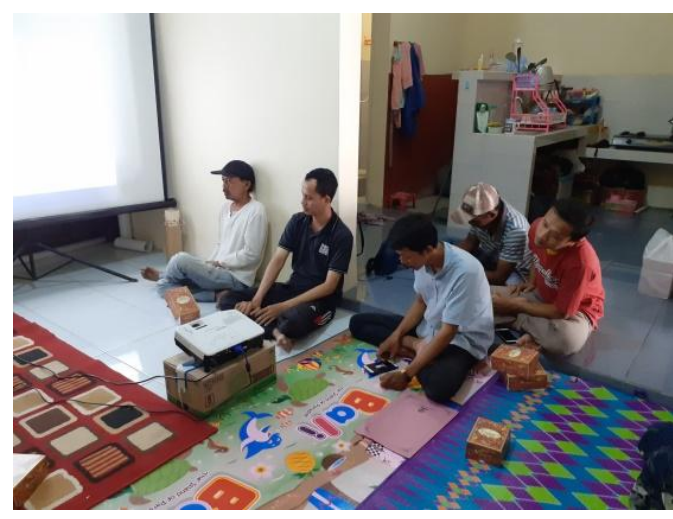

Gambar 1 Pelaksanaan Kelas Project

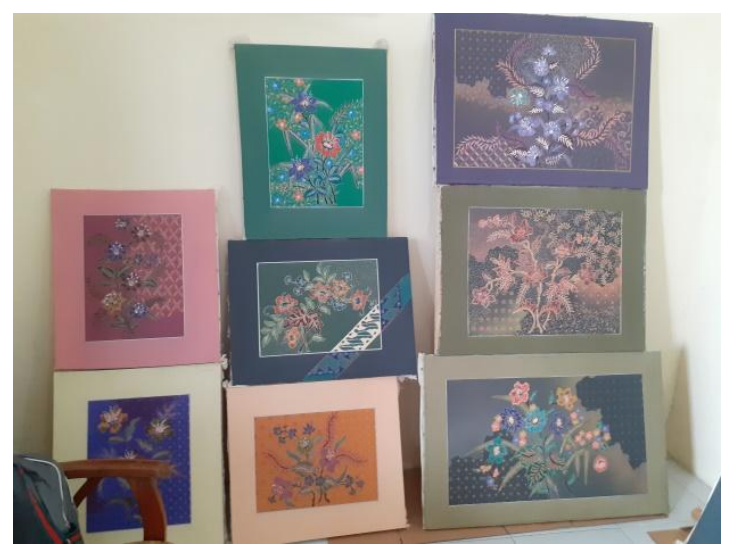

Gambar 3 Produk motif batik Pekalongan

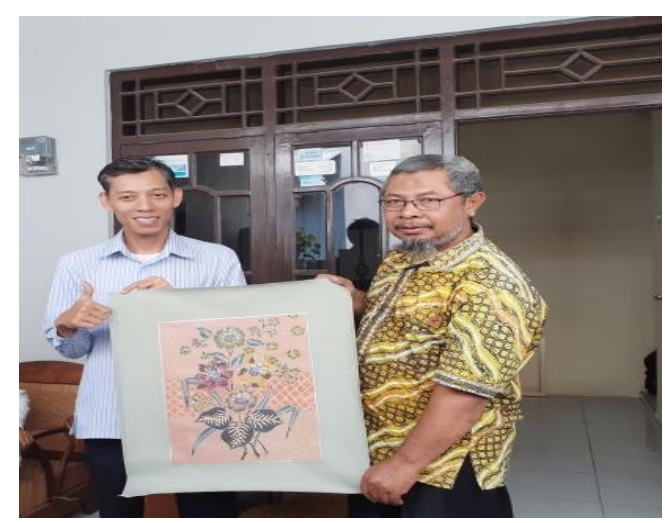

Gambar 2 Produk belum di finishing

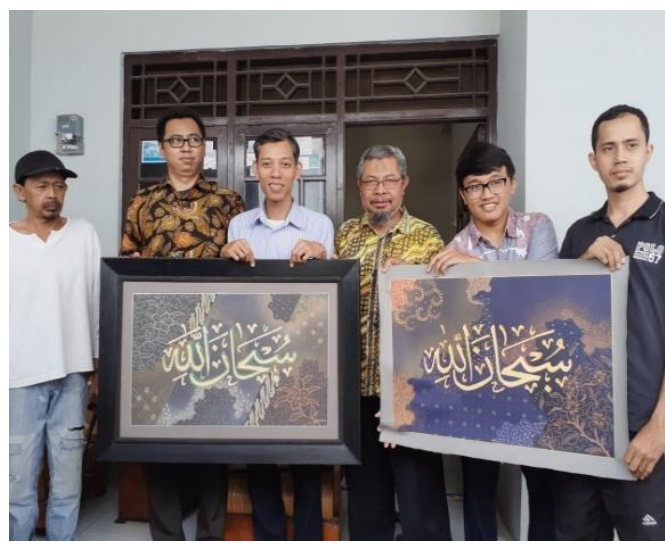

Gambar 4 Produk Batik Kaligrafi

\section{c. Peningkatan Pendapatan}

PKM kepada usaha produktif bertujuan untuk meningkatkan pendapatan dari sebuah kelompok usaha. Dalam hal ini peningkatan omset terjadi pada Asosiasi Aksi Muda Bina Griya, peningkatan ini sesuai dengan tujuan dilaksanakan program pengabdian masyarakat. 
Adapun data omset penjualan Januari - September 2019 adalah sebagai berikut:

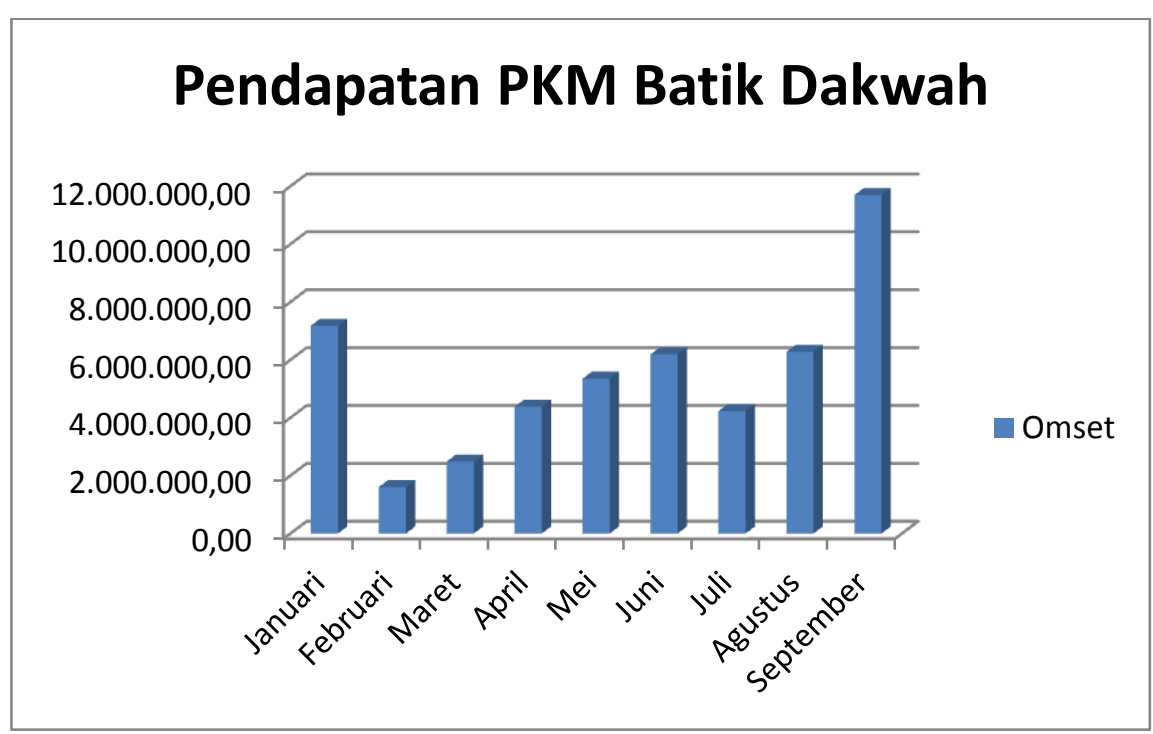

Sumber: Laporan Keuangan Mitra Asosiasi Aksi Muda Januari-September 2019.

Gambar 5 Grafik Pendapatan Batik Dakwah

Dari data pendapatan batik dakwah Asosiasi Aksi Muda diatas dapat dilihat bahwa terjadi kenaikan pendapatan di bulan september sebesar Rp. 11.693.000.

\section{KESIMPULAN}

Program pengabdian masyarakat (PPM) Pengabdian Kepada Masyarakat (PKM) telah dilaksanakan di Pringrejo Kota Pekalongan dengan tema PKM Pengembangan Batik sebagai Media Dakwah bagi Asosiasi Aksi Muda Bina Griya Pringrejo Pekalongan Barat Kota Pekalongan Jawa Tengah, sebagai berikut: Kelas project 1 yang menanamkan keilmuwan dan praktek etika bisnis Islam. Kelas project 2 menumbuhkan kecintaan kepada motif batik pekalongan Kelas project 3 menciptakan inovasi produk yang belum pernah ada dengan mengedepankan keberkahan produk Kelas project 4 pemahaman tentang persaingan usaha dan pembuatan digital marketing berupa instagram. Produk yang dihasilkan berupa Kaligrafi yang dipadukan dengan ukiran batik khas pekalongan, dan terdapat peningkatan omset bagi mitra binaan.

\section{SARAN}

Dengan adanya kegiatan pengabidan kepada masyarakat melalui peningkatan produksi dan pemasaran di Asosiasi Aksi Muda tersebut, diharapkan mampu meningkatkan nilai tambah dan keberlanjutan usahanya. 


\section{UCAPAN TERIMAKASIH}

Dalam mensukseskan pelaksanaan kegiatan Pengabdian Masyarakat ini, Penulis mengucapkan terimakasih kepada :

a. Kemenristekdikti dan LLDIKTI wilayah 6.

b. Universitas Muhammadiyah Pekajangan Pekalongan (UMPP) melalui Lembaga Penelitian Pengabdian dan Inovasi LPPI UMPP.

c. Fakultas Ekonomika dan Bisnis (FEB) UMPP melalui LP3M Fakultas Ekonomika dan Bisnis UMPP.

\section{DAFTAR PUSTAKA}

[1]. Kusnin, Asa, 2006, Batik Pekalongan Dalam Lintasan Sejarah, Paguyuban Pecinta Batik Pekalongan, Jakarta.

[2]. Karim, Adiwarman A., 2016, Ekonomi Mikro Islam, Cet. 8, PT. Raja Grafindo Persada, Jakarta.

[3]. Suprayitno, Eko, 2005, Ekonomi Islam, Graha Ilmu., Cetakan pertama, Yogyakarta

[4]. Norvadewi. 2015. Bisnis Dalam Perspektif Islam (Telaah Konsep, Prinsip dan Landasan Normatif). Jurnal Ekonomi dan Bisnis Islam AL-TIJARY. Vol. 01, No. 01. 